\title{
Electrodes criticality: the impact of CRMs in the leachate electrochemical oxidation
}

\author{
Mattia Pierpaoli ${ }^{1, *}$, Michał Rycewicz ${ }^{1}$, Aneta Łuczkiewicz ${ }^{2}$, Sylwia Fudala-Ksiązek ${ }^{2}$, Robert Bogdanowicz ${ }^{1}$, \\ and Maria Letizia Ruello ${ }^{3}$ \\ ${ }^{1}$ Faculty of Electronics, Telecommunications and Informatics, Gdańsk University of Technology, 11/12 G. Narutowicz St, \\ Gdańsk 80-980, Poland \\ ${ }^{2}$ Faculty of Civil and Environmental Engineering, Gdańsk University of Technology, 11/12 G. Narutowicz St, Gdańsk 80-980, \\ Poland \\ 3 Department of Materials, Environmental Sciences and Urban Planning, Università Politecnica delle Marche, \\ Via Brecce Bianche 12, Ancona, 60131, Italy
}

Received: 13 November 2019 / Accepted: 22 January 2020

\begin{abstract}
Landfill leachate possesses high concentrations of ammonia, micropollutants, and heavy metals, and are characterised for low biodegradability. For this reason, conventional treatment technologies may result ineffective for complete pollutant removal. Electrochemical oxidation allows most of the of recalcitrant pollutants to be oxidised effectively within an easy operational and acceptable retention time, without the need to provide additional chemicals, and without producing waste materials. The mineralisation efficiency and electrode durability depend on the nature of the electrode material. The conventionally adopted anodes can contain critical raw materials (CRMs), and are subject to extreme corrosion conditions. CRM-free electrodes, such as carbon and graphite-based, exhibit a lower efficiency, and are subject to faster deactivation, or, as for lead-dioxide-based electrodes, can constitute a hazard due to the release into the effluent of the coating corrosion products. In this study, the relationship between electrode type, CRM content, and the removal efficiencies of organic compounds and ammonium-nitrogen $\left(\mathrm{N}_{-} \mathrm{NH}_{4}\right)$ was investigated. Material criticality was estimated by the supply risk with economic importance indexes reported in the 2017 EU CRM List. The COD and N-NH removal efficiencies were obtained from a literature analysis of 25 publications. The results show that, while single and multi-oxide-coated electrodes may contain low amounts of CRM, but with limited efficiency, borondoped diamonds (BDD) may constitute the best compromise in terms of a reduced content of CRM and a high mineralisation efficiency.
\end{abstract}

Keywords: Recalcitrant pollutants / anodic oxidation / mineralisation efficiency / critical raw materials / boron-doped diamonds / advanced oxidation process

\section{Introduction}

Leachate production is major problem for municipal landfills because of its high content of refractory organic pollutants, ammonium-nitrogen, heavy metals [1], and micropollutants of emerging interest [2], which increases the treatment and disposal costs.

Electrochemical oxidation (EO) has attracted growing interest as an alternative to, or to be used jointly with, traditional treatment methods because of its easiness, scalability, modularity, ease of implementation, low cost, and high potential to oxidise refractory compounds. The basic set-up of an electrochemical oxidation unit comprises

\footnotetext{
* e-mail: mattia.pierpaoli@gmail.com
}

two electrodes (a cathode and an anode), a direct current power supply, and an electrolyte. The electrochemical oxidation of pollutants, commonly found in landfill leachates, can be categorised into two types: direct oxidation, in which species are oxidised at the anode, and indirect oxidation, in which the oxidation is carried out by secondary species (such as chlorinated compounds) originated at the electrodes.

The anode material is of primary importance in reactor design, as it should be characterised by high stability, low corrosion, low cost, and exhibit high activity toward pollutant oxidation and low oxygen evolution.

While the use of platinum for the oxidation of various organic compounds is widely reported in the literature, and is characterised by high inertness and corrosion resistance, its application in full-scale application is 
Table 1. Electrodes used for the electrochemical oxidation of landfill leachates reported in the literature.

\begin{tabular}{|c|c|c|c|c|}
\hline Electrode type* & Advantages & Disadvantages & CRM content & References \\
\hline Noble metal & $\begin{array}{l}\text { Repeatability } \\
\text { Stability }\end{array}$ & $\begin{array}{l}\text { Expensive material use } \\
\text { Low mineralization efficiency }\end{array}$ & High & $\mathrm{Pt}[3], \mathrm{Ti} / \mathrm{Pt}[4,5]$ \\
\hline $\mathrm{PbO}_{2}$ & Cheap & $\begin{array}{l}\text { Potential leaching of toxic } \\
\text { corrosion products } \\
\text { Poor performance }\end{array}$ & Absent/Low & $\begin{array}{l}\mathrm{PbO}_{2}[5] \\
\mathrm{Ti} / \mathrm{PbO}_{2}[9-12] \\
\mathrm{Ti} / \mathrm{Pt} / \mathrm{PbO}_{2}[13,14]\end{array}$ \\
\hline SMO & Stability & $\begin{array}{l}\text { Potential leaching of toxic } \\
\text { corrosion products }\end{array}$ & Low & $\mathrm{Ti} / \mathrm{RuO}_{2}[9,15] \mathrm{Ti} / \mathrm{SnO}_{2}[11]$ \\
\hline MMO & Stability & $\begin{array}{l}\text { Reproducibility } \\
\text { Potential leaching of toxic } \\
\text { corrosion products }\end{array}$ & Medium/Low & 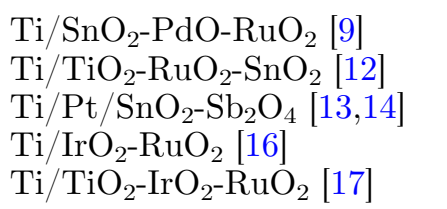 \\
\hline $\mathrm{a}-\mathrm{C}$ & Cheap & $\begin{array}{l}\text { Electrode corrosion } \\
\text { Low mineralization efficiency }\end{array}$ & Absent & $\begin{array}{l}\text { Graphite }[5,9,18] \\
\text { Graphite/PVC [19] }\end{array}$ \\
\hline BDD & $\begin{array}{l}\text { High mineralization } \\
\text { efficiency }\end{array}$ & Expensive setup & Low & {$[7,12-14,20-25]$} \\
\hline
\end{tabular}

*SMO: Single-metal oxide; MMO: Multi-metal oxide; a-C: amorphous carbon (graphite); BDD: boron-doped diamonds.

minimal [3], mainly because of the high costs; an aspect which is reflected in its criticality. For this reason, Pt-coated titanium electrodes represent a valid alternative $[4,5]$.

Titanium is a preferential substrate candidate for electrode fabrication because of its physical and electrical properties. Hereafter, titanium is widely used for the fabrication of dimensionally stable anodes (DSAs), in which a single metal oxide (SMO) or multiple metal oxides (MMO) are coated in the exposed part of the electrode. The most widely adopted technique to prepare DSA electrodes is the thermal decomposition of selected metal chloride precursors over a titanium substrate; with this method, the thicknesses and surface loading can be varied by the number of process iterations. For these reasons, this process is considered to be simple and low cost.

Among the $\mathrm{SMOs}$, the $\mathrm{PbO}_{2}$-coated electrode has been separately considered for two reasons: for the production method, and due to environmental concerns. $\mathrm{PbO}_{2}$ is characterised by low price, high efficiency, chemical inertness, and it can be deposited by electrochemical deposition, but the potential release of toxic corrosion products constitutes a significant environmental concern.

Carbon and graphite electrodes (here denominated as amorphous-carbon, a-C, electrodes) are characterised by a large surface area, high adsorption potential, and low cost; on the other hand, a-C electrodes are subjected to pronounced corrosion.

Jointly with a-C electrodes, different carbon allotropes have recently been investigated for electrochemical applications. Boron-doped diamond (BDD) electrodes exhibits high mechanical and corrosion resistance, chemical inertness, and a wide potential window. BDD deposition is done by chemical vapour deposition (CVD); in particular, hot filament (HFCVD), and plasma-assisted (PACVD) chemical vapour depositions are the most employed methods. However, up to nowadays, only the application with BDD has been investigated for leachate treatment. While it is possible to change the synthesis parameters to confer different physical and electrical properties to the electrode [6], the available literature lacks studies comprising a BDD electrode characterisation, or describing the electrode fabrication process. Currently, only the work by Fudala-Ksiazek et al. [7] investigated the effect of boron doping in BBD for the electrochemical oxidation of raw landfill leachate.

Critical raw materials (CRM) are materials of which concern is growing within the European Union (EU) due to their unreliable and hindered access [8]. For this reason, the European Commission has created a list of CRMs for the EU, which is regularly updated. The currently adopted methodology to assess such materials is based on a calculation which takes into account the economic importance, the possibility of substitution, and the EU supply risk (which is comprised of the EU/world share, geopolitical governance, substitution, and recycling rate) [8]. Conventionally adopted anodes for the electrochemical oxidation of landfill leachates may contain critical raw materials (Tab. 1), such as platinum, iridium, ruthenium, and antimony; however CRM-free electrodes, such as carbon and graphite-based ones, exhibit a lower efficiency, and they are subjected to a faster deactivation, or, as for lead-dioxide based electrodes, they can constitute a hazard because of the release into the effluent of the coating corrosion products.

The aim of this study is to compare the "criticality" of the currently employed electrodes to their efficiency, in terms of chemical oxygen demand (COD) and ammoniumnitrogen $\left(\mathrm{N}-\mathrm{NH}_{4}\right)$ removal efficiencies, for the oxidation of landfill leachate. In order to estimate the electrode's criticality, an index has been introduced, which is a function of both the supply risk, and economic importance, weighted based on the amount of raw materials contained within the electrode active layer. For this reason, and due to the lack of information in the available literature, the impact of the substrate has been neglected. 
Table 2. Electrode criticality.

\begin{tabular}{|c|c|c|c|c|}
\hline Reference & Electrode type & Electrode & Fabrication method* & Critical index $(\mathrm{Ci})$ \\
\hline Rolewicz et al. 1988 [29] & $\mathrm{SMO}$ & $\mathrm{Ti} / \mathrm{IrO}_{2}$ & $\mathrm{TD}$ & 0.040 \\
\hline \multirow[b]{2}{*}{ Kim et al. 2001 [30] } & $\mathrm{SMO}$ & $\mathrm{Ti} / \mathrm{RuOx}$ & $\mathrm{TD}$ & 0.018 \\
\hline & MMO & $\mathrm{Ti} / \mathrm{RuO}_{2}-\mathrm{SnO}_{2}-\mathrm{TiO}_{2}$ & $\mathrm{TD}$ & 0.037 \\
\hline Lipp et al. 1997 [31] & $\mathrm{SMO}$ & $\mathrm{Ti} / \mathrm{SnO}_{2}$ & $\mathrm{TD}$ & 0.061 \\
\hline \multirow[b]{2}{*}{ Ribeiro et al. 2004 [32] } & $\mathrm{MMO}$ & $\mathrm{Ti} / \mathrm{RuO}_{2}-\mathrm{Ta}_{2} \mathrm{O}_{5}$ & $\mathrm{TD}$ & $2.7-4.9$ \\
\hline & MMO & $\mathrm{Ti} / \mathrm{RuO}_{2}-\mathrm{TiO}_{2}$ & $\mathrm{TD}$ & 0.064 \\
\hline \multirow[t]{2}{*}{ Coteiro et al. 2006 [33] } & MMO & $\mathrm{Ti} / \mathrm{RuO}_{2}-\mathrm{SnO}_{2}-\mathrm{TiO}_{2}$ & $\mathrm{TD}$ & $0.056-0.077$ \\
\hline & MMO & $\mathrm{Ti} / \mathrm{RuO}_{2}-\mathrm{TiO}_{2}$ & $\mathrm{TD}$ & 0.023 \\
\hline \multirow{2}{*}{ Zafar et al. 2016 [34] } & MMO & $\mathrm{Ti} / \mathrm{RuO}_{2}-\mathrm{TiO}_{2}-\mathrm{SnO}_{2}$ & $\mathrm{TD}$ & 0.071 \\
\hline & MMO & $\mathrm{Ti} / \mathrm{RuO}_{2}-\mathrm{TiO}_{2}-\mathrm{IrO}_{2}$ & $\mathrm{TD}$ & 0.034 \\
\hline Fudala-Ksiazek et al. 2018 [7] & $\mathrm{BDD}$ & $\mathrm{Si} / \mathrm{BDD}$ & MPCVD & $0.084-0.168$ \\
\hline Andreade et al. 2007 [35] & MMO & $\mathrm{Ti} / \mathrm{Pt} / \mathrm{PbO}_{2}$ & $\mathrm{ECD}+\mathrm{TD}$ & $>0.77$ \\
\hline Ciriaco et al. 2009 [36] & MMO & $\mathrm{Ti} / \mathrm{Pt} / \mathrm{PbO}_{2}$ & $\mathrm{ECD}+\mathrm{TD}$ & $>0.70$ \\
\hline \multirow[b]{2}{*}{ Xu et al. 2013 [37] } & MMO & $\mathrm{Ti} / \mathrm{PbO}_{2}-\mathrm{SnO}_{2}$ & $\mathrm{TD}+\mathrm{ECD}$ & 1.27 \\
\hline & $\mathrm{PbO}_{2}$ & $\mathrm{Ti} / \mathrm{PbO}_{2}$ & $\mathrm{ECD}$ & 1.24 \\
\hline \multirow[b]{2}{*}{ Polcaro et al. 1999 [38] } & SMO & $\mathrm{Ti} / \mathrm{SnO}_{2}$ & $\mathrm{TD}$ & 0.024 \\
\hline & $\mathrm{PbO}_{2}$ & $\mathrm{Ti} / \mathrm{PbO}_{2}$ & ECD & 0.22 \\
\hline Vlyssides et al., 2001 [3] & $\mathrm{Pt}$ & $\mathrm{Pt}$ & - & 14 \\
\hline \multirow{3}{*}{ Wesselmark et al. 2005 [39] } & Platinised titanium & $\mathrm{Ti} / \mathrm{Pt}$ & & 0.016 \\
\hline & Porous Pt & $\mathrm{Ti} / \mathrm{Pt}$ & & 0.003 \\
\hline & Platinised titanium & $\mathrm{Ti} / \mathrm{Pt}$ & & 0.004 \\
\hline
\end{tabular}

${ }^{*}$ TD: thermal decomposition; ECD: electrochemical deposition.

\section{Data and methods}

In total, 112 observations were collected from 25 different publications focused on the electrochemical oxidation of landfill leachate. The adopted electrodes were classified into one of the categories presented in Table 1. Experimental data were obtained from the text, where available, or estimated from the plots. follows:

The specific electrical charge, $Q$, has been calculated as

$$
Q=\frac{J A t}{V}
$$

where $J$ is the applied current density $\left(\mathrm{A} / \mathrm{m}^{2}\right), A$ is the anode area $\left(\mathrm{m}^{2}\right), t$ is the test duration (h), and $V$ is the volume of the leachate $\left(\mathrm{dm}^{3}\right)$.

In order to estimate the "Critical index" $(\mathrm{Ci})$, the Euclidean distance was computed between the weighted supply risk $\left(\mathrm{SR}_{\mathrm{j}}\right)$ and economic importance $\left(\mathrm{EI}_{\mathrm{j}}\right)$ indexes, for all of the elements present on the electrode working surface, normalised by the electrode area $(A)$, the element fraction ratio $(\alpha j)$, and the atomic weight $\left(\mathrm{AW}_{\mathrm{j}}\right)$, as reported in equation (2):

$$
C i=\frac{1}{A} \sqrt{\left(\sum_{j} \frac{\alpha_{j} S R_{j}}{A W_{j}}\right)^{2}+\left(\sum_{j} \frac{\alpha_{j} E I_{j}}{A W_{j}}\right)^{2}},
$$

where the element fraction ratio has been measured experimentally (i.e. by EDX) or estimated by the authors.

The supply risk and economic importance indexes were obtained from the 2017 EU CRM list [26].

It is important to point out that, while according to the European definition of CRMs, only if both indices of a material exceed a threshold, can they be considered such, in this work, the electrode "criticality" is differently expressed: firstly, it is an extensive property, as it considers the material mass, normalised on the electrode area, and secondly, materials which are not considered "critical" by the EU definition have been taken into account for the index estimation.

While only a few authors provide a description of the electrode composition or references to the electrode fabrication, the estimation of the "Critical index" was evaluated by the literature reported in Table 2 . An example of the computation is reported in the Appendix A.

Data elaboration was performed with the $\mathrm{R}$ software [27] and visualised by using the ggplot2 library [28].

\section{Results and discussion}

\subsection{COD removal efficiency}

The efficiency of the electrochemical oxidative process was evaluated in terms of $\mathrm{COD}$ and $\mathrm{N}-\mathrm{NH}_{4}$ removal, and it depends on the test parameters and boundary conditions. 


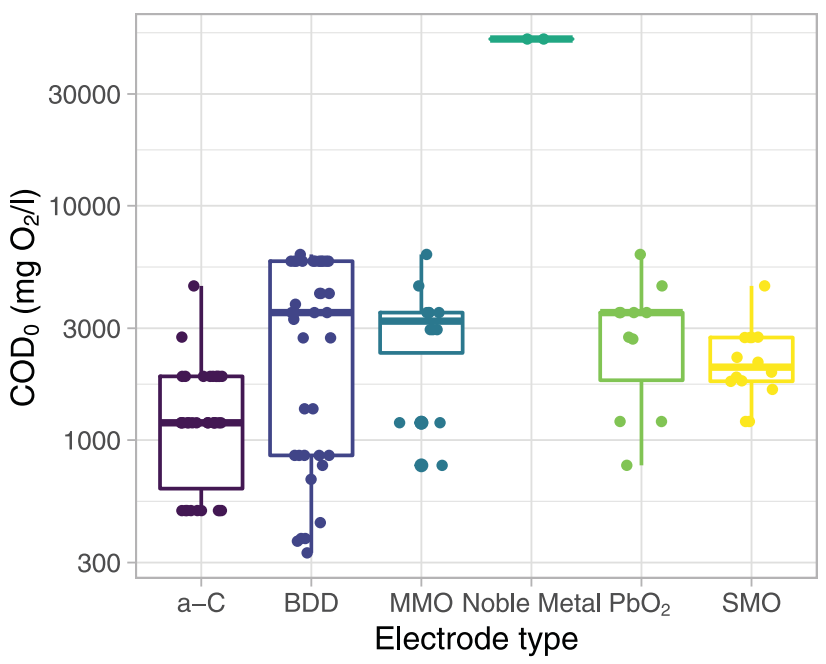

(a)

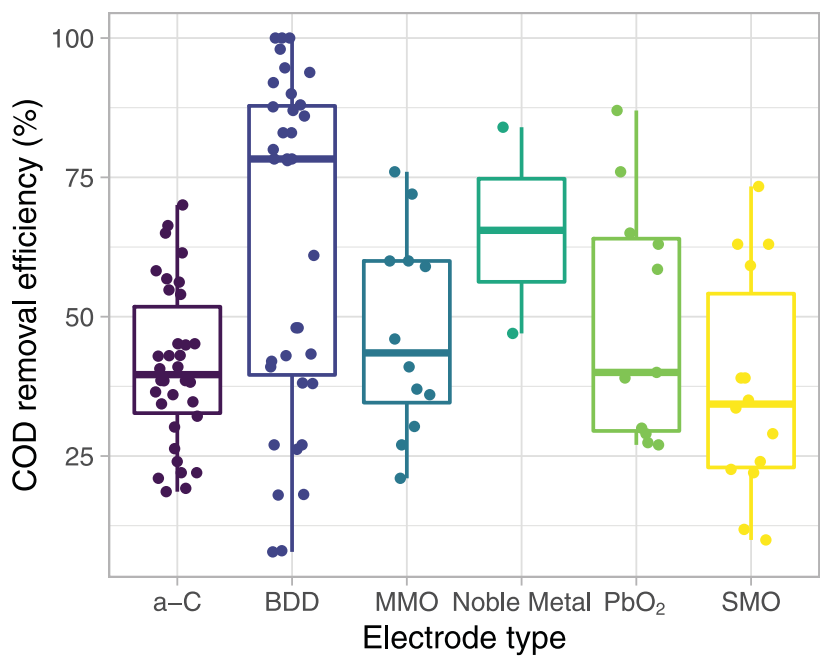

(b)

Fig. 1. Boxplots of (a) the initial COD concentration and (b) the COD removal efficiency for every considered test, grouped by electrode type.

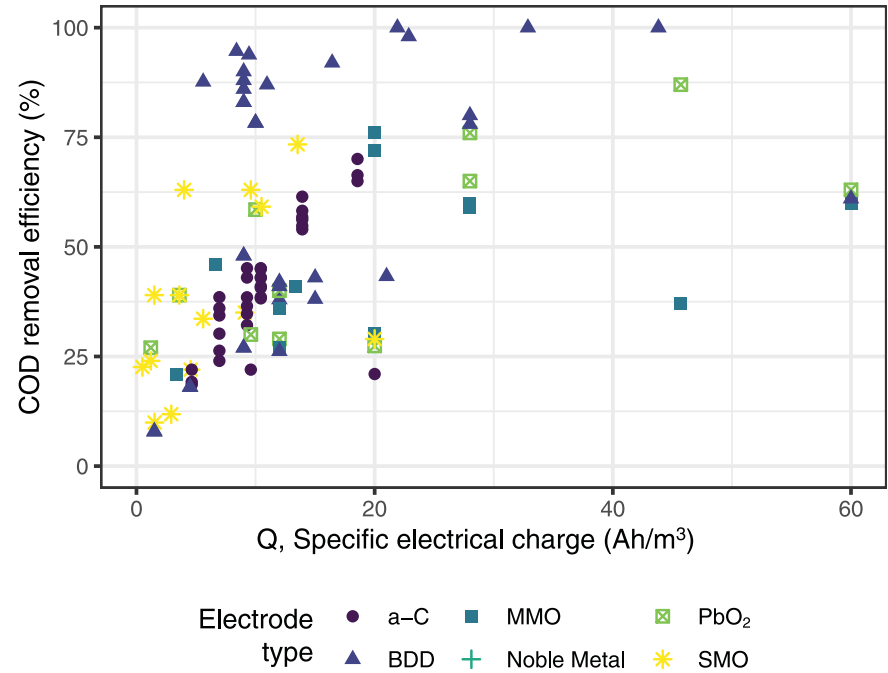

Fig. 2. COD removal efficiencies versus the specific electrical charge.

In this study, we mainly focused on the role of the anode material, with its intrinsic properties, while we tried to minimise the other operational parameters. Current density, reactor geometry, $\mathrm{pH}$, temperature, and electrical conductivity are the major factors influencing the process, and their values have been summarised in Appendix B. For most of the studies, the COD initial concentration ranges within an order of magnitude, having a median of $1870 \mathrm{mg}$ $\mathrm{O}_{2} /$ l, with an exception being the study conducted by Vlyssides et al. [3] (Fig. 1a), where it was equal to $51500 \mathrm{mg}$ $\mathrm{O}_{2} /$ l. COD removal efficiencies, grouped by electrode type, are reported in Figure 1b. For each boxplot, the box midline is the median, with the upper and lower limits of the box representing the third and first quartiles (respectively, the 75th and 25th percentile).The whiskers extend for 1.5 times the interquartile range. The jitters within the boxplots are the experimental observation used for calculation, while the points external to the extents of the whiskers are classified as outliers.

The COD removal efficiency $\left(\mathrm{COD}_{\text {eff }}\right)$ is expressed, by the different authors, as the ratio between the removed $\mathrm{COD}$ at a specific time $(\mathrm{COD} t)$, over the initial COD concentration $\left(\mathrm{COD}_{0}\right)$, as follows:

$$
\mathrm{COD}_{\text {eff }}=\frac{\mathrm{COD}_{0}-\mathrm{COD}_{t}}{\mathrm{COD}_{0}} \times 100
$$

However, this parameter is a function of the experimental and initial conditions, such as the type of leachate, the process duration, the initial COD concentration, the applied current density, the reactor type, and geometry. As the experimental conditions can be comparable for certain aspects, the leachate compositions may vary due to the landfill age, waste pre-treatments, and the contribution of technological wastewaters $[1,2,41]$. While the oxidation rate is represented by the decreasing of the COD concentration against time, the plotting of the COD removal efficiency against the specific electrical charge (Fig. 2) allows the process efficiency to be compared at different scales [42].

It is possible to observe a linear trend for different anode materials in the range of $0-30 \mathrm{Ah} / \mathrm{m}^{3}$, with the exception of some tests belonging to three publications [21,23,24], characterised by a higher removal efficiency at a lower specific electrical charge, in which BDD electrodes where employed. Two of those tests were conducted in a full-scale pilot plant. The study in which a Pt electrode was used is not reported in the plot for reasons of scale, as the specific electrical charge is equal to $100 \mathrm{Ah} / \mathrm{m}^{3}$. 


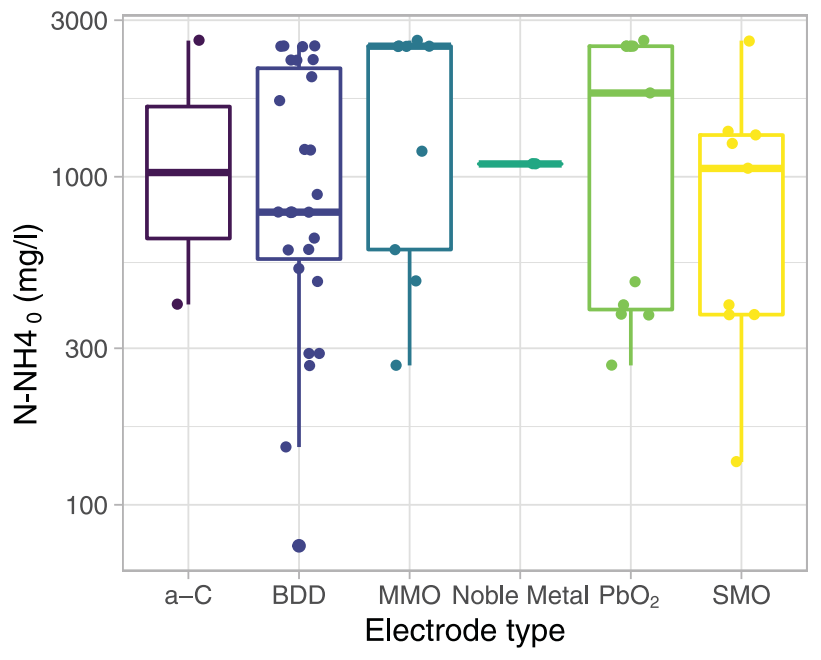

(a)

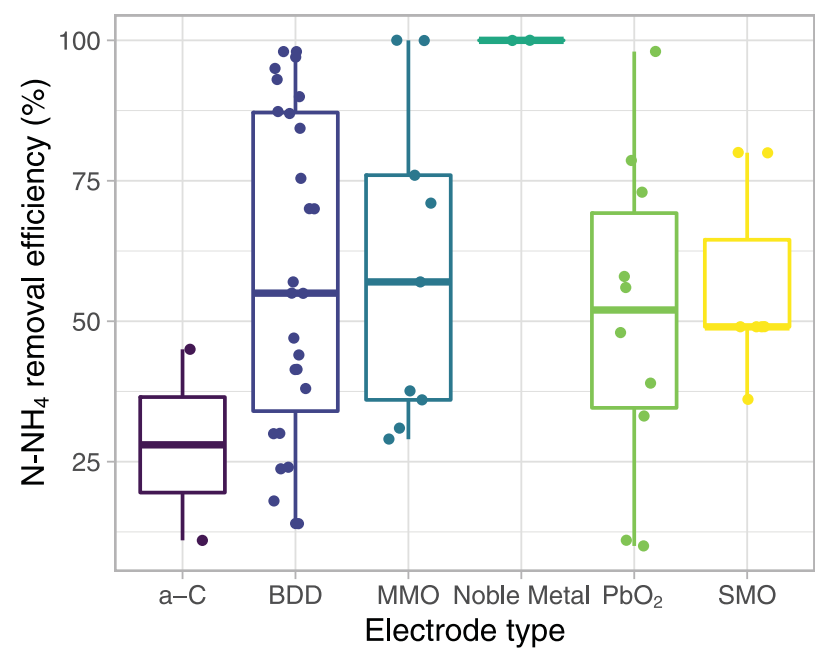

(b)

Fig. 3. Boxplots of (a) the initial $\mathrm{N}_{-} \mathrm{NH}_{4}$ concentration and (b) the $\mathrm{NH}_{4}$ removal efficiency for every considered test, grouped by electrode type.

\section{$3.2 \mathrm{~N}-\mathrm{NH}_{4}$ removal efficiency}

In general, for the analysed studies, the initial ammonium nitrogen concentration varies within an order magnitude, from 300 to $3000 \mathrm{mg} / \mathrm{m}^{3}$ (Fig. 3a). The ammonium removal rate varied widely between both the electrode type and within the same electrode category (Fig. 3b).

Differently from the COD removal efficiency, $\mathrm{NH}_{4}$ removal efficiency did not depend linearly on the specific electrical charge (Fig. 4). This can be explained by the fact that ammonium nitrogen is mainly removed through indirect reaction paths, which include the formation of chlorinated compounds [43], and depends on other factors, such as the presence of chlorates [5].

A material-based electrode investigation has been performed by a few authors [7,10-14], and the results are not always univocal and comparable. Table 3 summarises the main findings.

According by Chiang et al. [10], a ternary Ti/Sn-Pd$\mathrm{Ru}$ mixed oxide performed better than a $\mathrm{Ti} / \mathrm{PbO}_{2}$ electrode, while for Panizza et al. [12], a Ti/ $\mathrm{PbO}_{2}$ showed higher efficiency compared to a Ti/Ti-Ru-Sn, both for $\mathrm{COD}$ and $\mathrm{N}-\mathrm{NH}_{4}$ removal. Substantial differences did not arise when a $\mathrm{Ti} / \mathrm{PbO}_{2}$ electrode was compared to a $\mathrm{Ti} / \mathrm{SnO}_{2}$, according to Cossu et al. [11]. BDD electrodes performed better [12] or similarly $[13,14]$ to the other mixed-oxide electrodes, and the boron doping level influenced the electrochemical activity and selectivity of the electrode surface due to a change in the $\mathrm{sp}^{3} / \mathrm{sp}^{2} \mathrm{BDD}$.

\subsection{Electrode critical index}

The critical indexes, computed with equation (2), based on the data collected from the literature reported in Table 2, have been summarised by electrode type and plotted as boxplots in Figure 5.

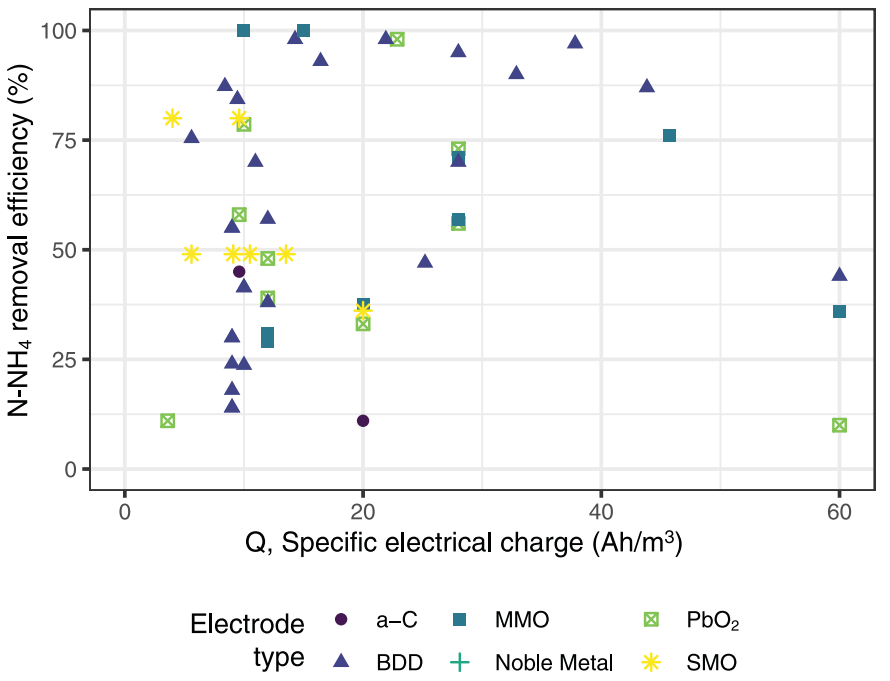

Fig. 4. $\mathrm{NH}_{4}$ removal efficiencies versus the specific electrical charge.

The production of SMO and MMO is well documented, both because of the different combinations of various metal oxides which are possible to deposit, and because of the different deposition techniques, precursor ratios, and coating thicknesses. Among SMOs, Pt-coated electrodes have also been reported, in order to differentiate them from the "noble metal category", which is represented only by the work of Vlyssides et al. [3]. In this case, for the computation, all of the electrode thicknesses were taken into account, instead of considering only the deposited layer. The BDD critical index was calculated from the work of Fudala-Ksiazek [7], relative to the three boron-doping ratios reported by MPCVD. As boron, hydrogen and methane are involved in the growth process, the presence of boron was used for the index computation. Differently 
Table 3. Studies in which a material-based electrode investigation was performed for the electrochemical oxidation of landfill leachates.

\begin{tabular}{|c|c|c|c|}
\hline Reference & COD removal efficiency & $\begin{array}{l}\mathrm{N}-\mathrm{NH}_{4} \text { removal } \\
\text { efficiency }\end{array}$ & Note \\
\hline Chiang et al. [10] & $\begin{array}{l}\mathrm{Ti} / \mathrm{Sn}-\mathrm{Pd}-\mathrm{Ru}>\mathrm{Ti} / \mathrm{Ru}-\mathrm{Ti}> \\
\mathrm{Ti} / \mathrm{PbO}_{2}>\text { graphite }\end{array}$ & & $\begin{array}{l}\text { correlation between the COD } \\
\text { removal efficiency and chlorine/ } \\
\text { hypochlorite production } \\
\text { removal of ammonium was } \\
\text { mainly due to the indirect } \\
\text { oxidation effect of chlorine/ } \\
\text { hypochlorite }\end{array}$ \\
\hline Cossu et al. [11] & $\mathrm{Ti} / \mathrm{PbO}_{2} \approx \mathrm{Ti} / \mathrm{SnO}_{2}$ & & $\begin{array}{l}\text { substantial differences did not } \\
\text { arise when the anodic material } \\
\text { was } \mathrm{Ti} / \mathrm{PbO}_{2} \text { or } \mathrm{Ti} / \mathrm{SnO}_{2}\end{array}$ \\
\hline Panizza et al. [12] & $\begin{array}{l}\mathrm{BDD}>\mathrm{Ti} / \mathrm{PbO}_{2}> \\
\mathrm{Ti} / \mathrm{Ti}-\mathrm{Ru}-\mathrm{Sn}\end{array}$ & & $\begin{array}{l}\text { with the } \mathrm{PbO}_{2} \text { anode, ammonium } \\
\text { and colour were completely } \\
\text { removed after } 8 \mathrm{~h} \text {; formation of } \\
\text { intermediates } \\
\text { complete COD, colour and } \\
\text { ammonium removal with BDD }\end{array}$ \\
\hline Fernandes et al. $[13,14]$ & $\begin{array}{l}\mathrm{BDD} \approx \mathrm{Ti} / \mathrm{Pt} / \mathrm{PbO}_{2} \approx \mathrm{Ti} / \\
\mathrm{Pt} / \mathrm{SnO}_{2}-\mathrm{Sb}_{2} \mathrm{O}_{4}\end{array}$ & $\begin{array}{l}\mathrm{Ti} / \mathrm{Pt} / \mathrm{PbO}_{2}> \\
\mathrm{BDD}>\mathrm{Ti} / \mathrm{Pt} / \\
\mathrm{SnO}_{2}-\mathrm{Sb}_{2} \mathrm{O}_{4}\end{array}$ & $\begin{array}{l}\text { ammonium to nitrate conversion } \\
\text { was higher in BDD than other } \\
\text { metal oxides } \\
\mathrm{COD} \text { and } \mathrm{N}-\mathrm{NH}_{4} \text { removal rates } \\
\text { increased with chloride ion } \\
\text { concentration, }\end{array}$ \\
\hline Fudala-Ksiazek [7] & $\begin{array}{l}\mathrm{BDD} 10 \mathrm{k} \approx \mathrm{BDD} \\
5 \mathrm{k} \approx \mathrm{BDD} 0.5 \mathrm{k}\end{array}$ & $\begin{array}{l}\text { BDD } 10 \mathrm{k} \approx \mathrm{BDD} 0.5 \mathrm{k}> \\
\text { BDD } 5 \mathrm{k}\end{array}$ & $\begin{array}{l}\text { a decrease in the } \mathrm{sp}^{3} / \mathrm{sp}^{2} \text { ratio of } \\
\text { the applied } \mathrm{BDD} \text { material } \\
\text { resulted in the elevated removal } \\
\text { efficiency of } \mathrm{N}^{-\mathrm{NH}_{4}}\end{array}$ \\
\hline
\end{tabular}

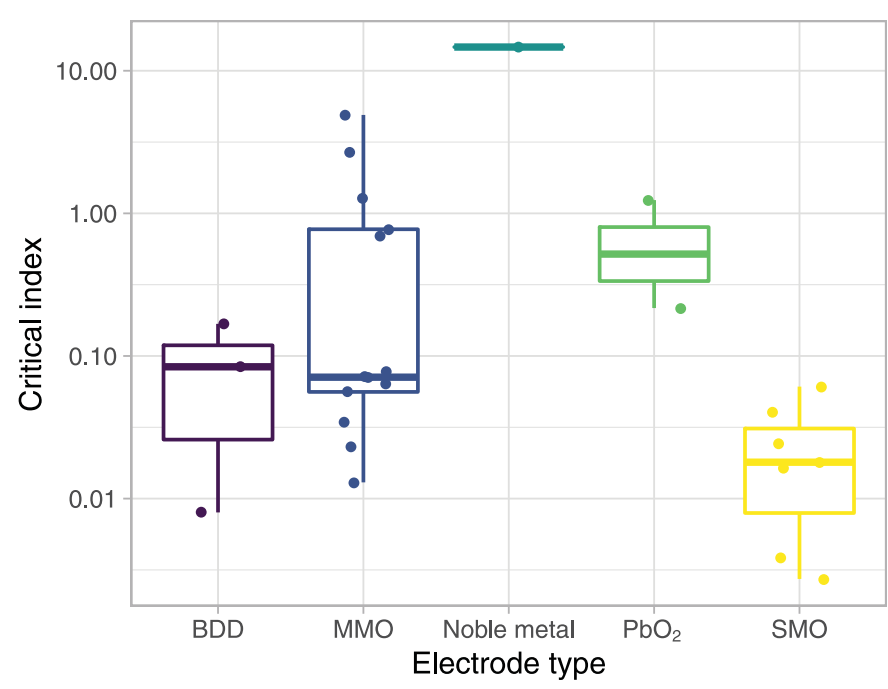

Fig. 5. Boxplot of the calculated critical indexes by electrode type. from the other computations, where the presence of the material was calculated a posteriori, from the nominal or the effective elemental composition of the "active" layer, in this case, the amount of boron has been calculated from the diborane gas used effectively to produce one electrode. a-C electrodes are absent from the plot, as they can be produced from any carbon material able to be turned into graphite.

By merging the data from Figure 1a and Figure 5 by electrode type, it is possible to correlate the calculated critical index interval with the COD removal efficiency. The results are graphed in Figure 6.

By considering the $\mathrm{SMO}, \mathrm{MMO}, \mathrm{PbO}_{2}$ and noble metal squares, it is possible to observe that "criticality" and COD removal efficiency increase simultaneously, while, BDD can reach high efficiency, even with a low critical index. When considering the ammonium nitrogen removal efficiency, it is not possible to distinguish any evident correlation with the electrode criticality (Fig. 7). 


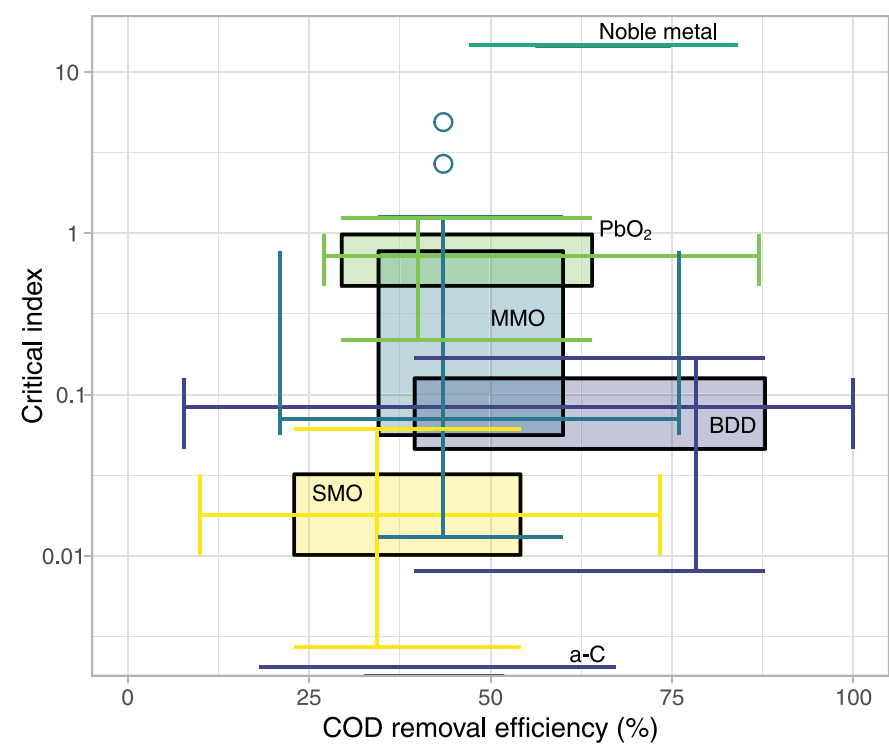

Fig. 6. Correlation between the material critical index and COD removal efficiency.

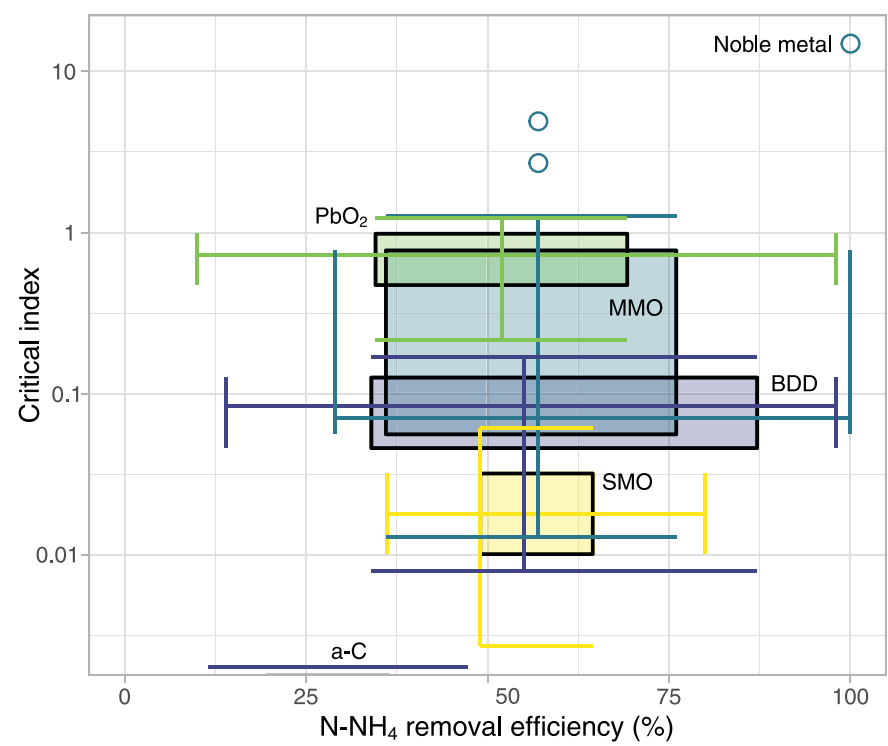

Fig. 7. Correlation between the material critical index and $\mathrm{N}-$ NH4 removal efficiency.

However, it is important to specify that the critical index is a function of the supply risk, and economic importance factors, which have been arbitrarily determined considering geopolitical, commercial, technological and supply factors. The utility of Figures 6 and 7 is to provide a straightforward indication of the electrode material, and not to justify an accidental correlation between the considered variables.

\section{Conclusions}

Electrochemical oxidation has proven to be an efficient process for removing recalcitrant compounds from heavily polluted landfill leachates by laboratory experiments reported in the literature; however, it has not found a large scale implementation because of the running costs, and the electrode stability. For this reason, the investigation of efficient, durable, and cost-effective electrode materials constitutes the primary concern for the large scale implementation of such technology. In this study, we tried to objectively quantify these aspects, in order to provide an overview of which electrode materials could meet both needs in terms of high efficiency and low "criticality". On the one hand, graphitic carbon is the cheapest, CRM-free alternative; however, it possesses the lowest $\mathrm{COD}$ and $\mathrm{N}-\mathrm{NH}_{4}$ removal efficiencies, and it is intensely subjected to the corrosion problem. On the other hand, platinum electrodes have been intensely studied for their high stability, efficiency, and repeatability; however the large-scale use of a critical raw material makes them unsuitable for full-scale applications. Among all the other electrodes investigated, BDD constitutes a preferential path for significantly decreasing the amount of CRM used, allowing high removal efficiency to be reached.

A limitation of this study is that, while for the a-C and noble metal anodes, the whole electrode has been considered, for the SMO, MMO and BDD, only the coating has been taken into account. This is justified by the fact that the support thickness is not always specified in the literature, as it does not affect the electrode efficiency, but the choice is due to material availability and the requirement of the set-up dimensions. DSA-electrodes are typically fabricated on Ti substrates, due to the good electrical conductivity, relative low cost, and high thermal resistance required by the thermal decomposition method. BDD can be grown on different substrates, such as $\mathrm{Si}, \mathrm{Nb}$, $\mathrm{Ti}$, and glassy carbon; however, $\mathrm{Si}$ is the most reported material for electrochemical oxidation applications.

Future developments includes the design and production of CVD-grown nanostructured electrodes having a reduced (or absent) content of critical raw material, characterised by high efficiency and stability towards the electrochemical oxidation of leachate refractory pollutants.

This publication is based upon work from COST Action CA15102 (Solutions for Critical Raw Materials Under Extreme Conditions) supported by COST (European Cooperation in Science and Technology) and by The Polish National Agency for Academic Exchange (NAWA), under the Ulam program, Agreement no. PPN/ULM/2019/1/00061/DEC/1. This work was also supported by the Provincial Fund for Environmental Protection and Water Management in Gdańsk under Grant No. RX15/13/2017.

\section{Appendix A: Example of computation of the Critical index for the reference Kim et al. $2001[30]$}

In the article, Kim et al. investigate the effect of annealing temperature in the preparation of $\mathrm{Ti} / \mathrm{Ru}-\mathrm{Sn}$-Ti electrodes.

As available, the nominal composition of the oxide has been used to estimate the elemental composition. If it is not provided by the text, the result from an elemental analysis has been used instead. In this case, the composition is the 
follow: $35 \% \mathrm{Ru}+39 \% \mathrm{Sn}+26 \% \mathrm{Ti}$ oxide. The net metal oxide layer, for a sintering temperature of $450{ }^{\circ} \mathrm{C}$, is equal to $0.24 \mathrm{mg} / \mathrm{cm}^{2}$ (extracted from the plot). Supply risk, Economic importance of each element has been taken from the CRM EU Guidelines [26] (Tab. A1).

Table A1. Values used for the Critical index computation.

\begin{tabular}{llll}
\hline & $\mathrm{Ru}$ & $\mathrm{Sn}$ & $\mathrm{Ti}$ \\
\hline Atomic mass (g/mol) & 101 & 118 & 48 \\
$\begin{array}{l}\text { Element relative weight in } \\
\text { the oxide form (-) }\end{array}$ & 0.76 & 0.79 & 0.60 \\
Supply risk (SR) & 3.4 & 0.8 & 0.30 \\
Economic importance (EI) & 3.5 & 4.4 & 4.30 \\
Electrode composition (\%) & 35 & 39 & 26 \\
\hline
\end{tabular}

By using equation (2), here reported for easiness, is it possible to obtain:

$$
\begin{gathered}
C i=\frac{1}{A} \sqrt{\left(\sum_{j} \frac{\alpha_{j} S R_{j}}{A W_{j}}\right)^{2}+\left(\sum_{j} \frac{\alpha_{j} E I_{j}}{A W_{j}}\right)^{2}} \quad(\mathrm{~A} 1) \\
C i=\frac{1}{1} \sqrt{(\underbrace{\left.0.76 \cdot \frac{35}{100} \cdot \frac{3.4}{101}+0.79 \cdot \frac{39}{100} \cdot \frac{0.8}{118}+0.6 \cdot \frac{26}{100} \cdot \frac{0.3}{48}\right)^{2}}_{\text {supply risk }}} \\
+(\underbrace{0.76 \cdot \frac{35}{100} \cdot \frac{3.5}{101}+0.79 \cdot \frac{39}{100} \cdot \frac{4.4}{118}+0.6 \cdot \frac{26}{100} \cdot \frac{4.3}{48}}_{\text {economic importance }})^{2} \\
=0.037
\end{gathered}
$$

\section{Appendix B: Descriptive statistics of the experiments reported in Table 1}

\section{References}

1. S. Fudala-Ksiazek, M. Pierpaoli, E. Kulbat, A. Luczkiewicz, Waste Manag. 49 (2016) 516-529

2. S. Fudala-Ksiazek, M. Pierpaoli, A. Luczkiewicz, Waste Manag. 64 (2017) 28-38

3. A. Vlyssides, P. Karlis, M. Loizidou, A. Zorpas, D. Arapoglou, Environ. Technol. 22 (2001) 1467-1476

4. F. Aloui, F. Fki, S. Loukil, S. Sayadi, Water Sci. Technol. 60 (2009) 605-614

5. F. Feki, F. Aloui, M. Feki, S. Sayadi, Chemosphere 75 (2009) 256-260

6. M. Pierpaoli, M. Ficek, M. Rycewicz, M. Sawczak, J. Karczewski, M. Ruello, R. Bogdanowicz, Materials (Basel). 12 (2019) 547

7. S. Fudala-Ksiazek, M. Sobaszek, A. Luczkiewicz, A. Pieczynska, A. Ofiarska, A. Fiszka-Borzyszkowska, M. Sawczak, M. Ficek, R. Bogdanowicz, E.M. Siedlecka, Chem. Eng. J. 334 (2018) 1074-1084

8. G.A. Blengini, et al., Methodology for Establishing the EU List of Critical Raw Materials: Guidelines, European Commision, Join Research Centre, Brussels, Belgium, 2017

9. L.-C. Chiang, J.-E. Chang, T.-C. Wen, Water Res. 29 (1995) 671-678

10. L.-C. Chiang, J.-E. Chang, C.-T. Chung, Environ. Eng. Sci. 18 (2001) 369-379

11. R. Cossu, et al., Electrochemical treatment of landfill leachate: oxidation at $\mathrm{Ti} / \mathrm{PbO}_{2}$ and $\mathrm{Ti} / \mathrm{SnO}_{2}$ anodes, Environ. Sci. Technol. 32 (1998) 3570-3573

12. M. Panizza, C.A. Martinez-Huitle, Chemosphere 90 (2013) $1455-1460$

13. A. Fernandes, D. Santos, M.J. Pacheco, L. Ciríaco, A. Lopes, Appl. Catal. B 148-149 (2014) 288-294

14. A. Fernandes, D. Santos, M.J. Pacheco, L. Ciríaco, A. Lopes, Sci. Total Environ. 541 (2016) 282-291

15. P.B. Moraes, R. Bertazzoli, Chemosphere. 58 (2005) 41-46

16. E. Turro, A. Giannis, R. Cossu, E. Gidarakos, D. Mantzavinos, A. Katsaounis, J. Hazard. Mater. 190 (2011) 460-465

17. L. Shao, P. He, J. Xue, G. Li, Water Sci. Technol. 53 (2006) 143-150

18. M.J.K. Bashir, M.H. Isa, S.R.M. Kutty, Z. Bin Awang, H.A. Aziz, S. Mohajeri, I.H. Farooqi, Waste Manag. 29 (2009) $2534-2541$

19. Z.H. Mussa, M.R. Othman, M.P. Abdullah, Electrochemical oxidation of landfill leachate: investigation of operational parameters and kinetics using graphite-PVC composite electrode as anode, J. Braz. Chem. Soc. 26 (2015) 939-948

Table B1. Descriptive statistics of the observations obtained from the literature reported in Table 1.

\begin{tabular}{llllll}
\hline & $\begin{array}{l}\text { Electrode } \\
\text { area }\left(\mathrm{cm}^{2}\right)\end{array}$ & $\begin{array}{l}\text { Reactor } \\
\text { volume }\left(\mathrm{dm}^{3}\right)\end{array}$ & $\begin{array}{l}\text { Initial COD } \\
(\mathrm{mg} \mathrm{O} / \mathrm{l})\end{array}$ & $\begin{array}{l}\text { Initial } \\
\mathrm{N}^{2} \mathrm{NH}_{4}(\mathrm{mg} / \mathrm{l})\end{array}$ & $\begin{array}{l}\text { Test duration } \\
(\mathrm{min})\end{array}$ \\
\hline Valid & 115 & 115 & 110 & 60 & 114 \\
Missing & 0 & 0 & 5 & 55 & 1 \\
Std. Deviation & 2141 & 47 & 6807 & 913 & 133 \\
Minimum & 0.785 & 0.04 & 330 & 75 & 60 \\
Maximum & 10500 & 230 & 51500 & 2600 & 480 \\
25th percentile & 10 & 0.20 & 1185 & 462 & 180 \\
50th percentile & 29 & 0.50 & 1870 & 1077 & 240 \\
75th percentile & 50 & 0.55 & 3500 & 2500 & 360 \\
\hline
\end{tabular}


20. A. Cabeza, A. Urtiaga, M.-J. Rivero, I. Ortiz, J. Hazard. Mater. 144 (2007) 715-719

21. A. Anglada, A. Urtiaga, I. Ortiz, Environ. Sci. Technol. 43 (2009) 2035-2040

22. F.C. Moreira, J. Soler, A. Fonseca, I. Saraiva, R.A.R. Boaventura, E. Brillas, V.J.P. Vilar, Water Res. 81 (2015) 375-387

23. A. Fernandes, M.J. Pacheco, L. Ciríaco, A. Lopes, J. Hazard. Mater. 199-200 (2012) 82-87

24. A. Urtiaga, A. Rueda, Á. Anglada, I. Ortiz, J. Hazard. Mater. 166 (2009) 1530-1534

25. C. Papastavrou, D. Mantzavinos, E. Diamadopoulos, Environ. Technol. 30 (2009) 1547-1553

26. EC, Study on the review of the list of critical raw materials, 2017. https://doi.org/10.2873/876644

27. R Core Team, R: A language and environment for statistical computing, R Foundation for Statistical Computing, Vienna, Austria, 2017, https://www.R-project.org/

28. H. Wickham, Ggplot2: elegrant graphics for data analysis, n.d. https://ggplot2.tidyverse.org/authors.html (accessed January 21, 2019)

29. J. Rolewicz, C. Comninellis, E. Plattner, J. Hinden, Electrochim. Acta 33 (1988) 573-580

30. K.-W. Kim, E.-H. Lee, J.-S. Kim, K.-H. Shin, K.-H. Kim, Electrochim. Acta 46 (2001) 915-921
31. L. Lipp, D. Pletcher, Electrochim. Acta 42 (1997) 1091-1099

32. J. Ribeiro, A.R. De Andrade, J. Electrochem. Soc. 151 (2004) 106-112

33. R.D. Coteiro, F.S. Teruel, J. Ribeiro, A.R. de Andrade, J. Braz. Chem. Soc. 17 (2006) 771-779

34. M.S. Zafar, M. Tausif, Zia-ul-Haq, M. Ashraf, S. Hussain, Port. Electrochim. Acta 34 (2016) 257-266

35. L.S. Andrade, L.A.M. Ruotolo, R.C. Rocha-Filho, N. Bocchi, S.R. Biaggio, J. Iniesta, V. García-Garcia, V. Montiel, Chemosphere 66 (2007) 2035-2043

36. L. Ciríaco, C. Anjo, J. Correia, M.J. Pacheco, A. Lopes, Electrochim. Acta 54 (2009) 1464-1472

37. H. Xu, Q. Zhang, W. Yan, W. Chu, L. Zhang, Int. J. Electrochem. Sci. 8 (2013) 5382-5395

38. A.M. Polcaro, S. Palmas, F. Renoldi, M. Mascia, J. Appl. Electrochem. 29 (1999) 147-151

39. M. Wesselmark, C. Lagergren, G. Lindbergh, Proc. Electrochem. Soc. PV 2004-18 (2004) 264-275

40. J.F. Patzer, S.J. Yao, S.K. Wolfson, J. Mol. Catal. 70 (1991) 217-230

41. S. Fudala-Ksiazek, M. Pierpaoli, A. Luczkiewicz, Waste Manag. 78 (2018) 94-103

42. A. Anglada, A. Urtiaga, I. Ortiz, J. Chem. Technol. Biotechnol. 84 (2009) 1747-1755

43. L. Li, Y. Liu, J. Hazard. Mater. 161 (2009) 1010-1016

Cite this article as: Mattia Pierpaoli, Michał Rycewicz, Aneta Łuczkiewicz, Sylwia Fudala-Ksiązek, Robert Bogdanowicz, Maria Letizia Ruello, Electrodes criticality: the impact of CRMs in the leachate electrochemical oxidation, Manufacturing Rev. 7, 7 (2020) 